\title{
Roles of a forest corridor between Marojejy, Anjana- haribe-Sud and Tsaratanana protected areas, nor- thern Madagascar, in maintaining endemic and threatened Malagasy taxa
}

Jeanneney Rabearivony', Maminiaina Rasamoelinal", Joel Raveloson"I', Hajanirina Rakotomananalv, Achille Philippe Raselimananalv, Noromalala Rasoamampionona Raminosoalv, John Rigobert Zaonarivelol

\section{ABSTRACT}

Site-based conservation is widely recognized as a fundamental requirement for the maintenance of biodiversity. We carried out a rapid biological assessment from 17 March to 14 May 2011 in the southwestern part of the provisionally protected rainforest corridor between Marojejy, Anjanaharibe-Sud and Tsaratanana protected areas (COMATSA), northern Madagascar, to assess its biodiversity richness and species conservation status. We recorded 248 endemic vertebrate species, including 80 amphibians, 52 reptiles, 79 birds, 27 small mammals and 10 lemurs. Of these 248 species, 36 are threatened including one Critically Endangered (one lemur), nine Endangered (two amphibians, four reptiles and three lemurs) and 26 Vulnerable (10 amphibians, six reptiles, four birds, one small mammal and five lemurs). For herpetofauna species, the pair COMATSA - Marojejy was the only site that had a similarity value greater than 0.50 . For birds and lemurs, values of similarity in three pairs of sites COMATSA - Marojejy, COMATSA - Anjanaharibe-Sud and Marojejy - Anjanaharibe-Sud exceeded those of herpetofauna in COMATSA - Marojejy. The inclusion of the COMATSA into the new protected area network in Madagascar is supported by our findings.

\section{RÉSUMÉ}

II est dorénavant largement reconnu que pour maintenir la biodiversité, il est fondamental de réaliser la conservation de la nature au niveau des sites. Un inventaire biologique rapide a été mené du 17 mars au 14 mai 2011 dans la partie sud-ouest du couloir forestier reliant les parcs et réserves du Marojejy, d'Anjanaharibesud et du Tsaratanana (COMATSA). L'inventaire de ce couloir qui bénéficie d'un statut de protection temporaire dans la partie septentrionale de Madagascar, était destiné à évaluer la richesse de sa biodiversité et le statut de conservation des espèces de vertébrés qu'il héberge. Les résultats ont montré que parmi les 248 espèces endémiques de vertébrés recensées, 80 sont des amphibiens, 52 des reptiles, 79 des oiseaux, 27 des petits mammi-
Correspondence:

Jeanneney Rabearivony

Faculty of Sciences, University of Antsiranana, Madagascar

E-mail: jeanneneyrabearivony@yahoo.com

fères et 10 des lémuriens. Sur ces 248 espèces, 36 sont menacées, dont une espèce qui est en Danger Critique d'Extinction (lémurien), neuf en Danger (deux amphibiens, quatre reptiles et trois lémuriens) et 26 Vulnérables (10 amphibiens, six reptiles, quatre oiseaux, un micromammifère et cinq lémuriens). Ce couloir forestier présente un coefficient de similarité élevé, d'une valeur supérieure à 0.50 avec le Marojejy pour les amphibiens et les reptiles. Pour les oiseaux et les lémuriens, les coefficients sont encore plus importants, plus particulièrement dans les comparaisons COMATSA - Marojejy, COMATSA - AnjanaharibeSud et Marojejy - Anjanaharibe-Sud. Cette étude confirme I'importance d'intégrer le COMATSA dans le réseau des Aires Protégées de Madagascar pour renforcer la protection des espèces de vertébrés endémiques et menacées.

\section{INTRODUCTION}

The in situ conservation of viable populations in natural ecosystems is widely recognized as being important in tackling global biodiversity loss (Nagendra 2008), and is considered to be the greatest hope for the conservation of most of globally threatened faunal groups (Boyd et al. 2008).

The Island of Madagascar is one of the world's highest biodiversity conservation priorities (Ganzhorn et al. 2001, Mittermeier et al. 2005), because of its exceptionally high endemism rate in plants and animals, as well as its relentless pace of forest ecosystem degradation (Myers et al. 2000). Biogeographic studies of several faunal groups in Madagascar show that northern and/or eastern Malagasy forest habitats are important in maintaining many endemic and threatened species of herpetofauna (Glaw and Vences 2007), birds (Hawkins and Goodman 2003) and lemurs (Tattersall 1982, Mittermeier et al. 2008); however, many conservation priority species are not represented within protected areas managed by Madagascar National Parks (MNP) (e.g., Andreone et al. 2001, Durkin et al. 2011). Therefore, the current extension of the Madagascar protected areas system will, undoubtedly, provide 


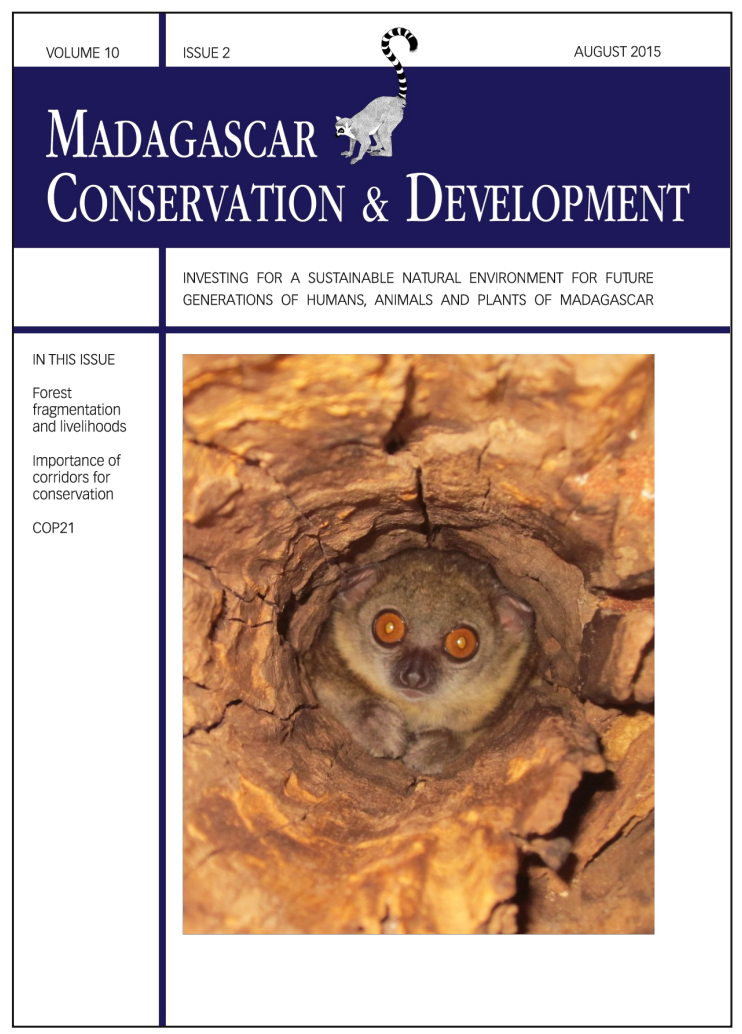

Madagascar Conservation \& Development is the journal of Indian Ocean e-Ink. It is produced under the responsibility of this institution. The views expressed in contributions to MCD are solely those of the authors and not those of the journal editors or the publisher.

All the Issues and articles are freely available at http://www.journalmcd.com

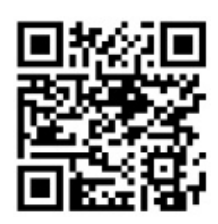

Contact Journal MCD

info@journalmcd.net for general inquiries regarding MCD funding@journalmcd.net to support the journal

Madagascar Conservation \& Development Institute and Museum of Anthropology

University of Zurich

Winterthurerstrasse 190

$\mathrm{CH}-8057$ Zurich

Switzerland

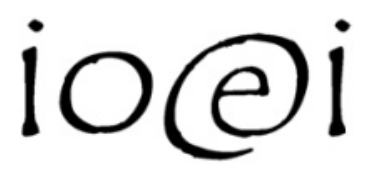

Indian Ocean e-Ink

Promoting African Publishing and Education

www.ioeink.com

Missouri Botanical Garden (MBG)

Madagascar Research and Conservation Program BP 3391

Antananarivo, 101, Madagascar 
more survival opportunities for those key species that are suffering from habitat loss outside of protected areas (Rabearivony et al. 2010)

Currently, the MNP protected areas cover about 1.7 million hectares and, in 2003, during the fifth World's Park Congress that was held in Durban, South Africa, the President of Madagascar stated his commitment to triple the amount of national protected area coverage (Mittermeier et al. 2005). Therefore, out of six IUCN's protected area categories adopted for Madagascar, three (IUCN category I = Strict Nature Reserve, IUCN category II = National Park and IUCN category IV = Special Reserve) are under the MNP's management and, after Durban's Congress; three additional categories (IUCN category III = Natural Monument, IUCN category $\mathrm{V}=$ Protected Landscape/Seascape and IUCN category VI = Sustainable use area) were adopted under the new protected area system known as SAPM (Système des Aires Protégées de Madagascar). As this new protected area system involved many stakeholders, the SAPM sites have to pass two-year provisional protection status to check if there is any resistance from certain concerned stakeholders and to ensure the stability of future reserves before they get definitive protection.

While most field studies in Madagascar are undertaken in MNP's protected areas, this study was carried out in the provisional protected forest corridor between Marojejy National Park, Anjanaharibe-Sud Special Reserve and Tsaratanana Strict Nature Reserve known as COMATSA (Corridor Marojejy, Anjanaharibe-Sud and Tsaratanana, Figure 1) in northern Madagascar. The faunal and floral communities of the southeastern part of COMATSA (Betaolana Forest corridor between Marojejy and Anjanaharibe-Sud) have previously been surveyed (Figure 1, Goodman et al. 2003a, Raherilalao and Goodman 2003, Rakotomalala and Raselimanana 2003, Soarimalala and Goodman 2003) leaving the other parts of the corridor unsurveyed. The COMATSA is known as biologically rich (Garreau and Manantsara 2003, Razafy and Andriamarosolo 2010). This study aims to: (i) assess its biodiversity richness and species conservation status to supplement the previous findings, and (ii) determine its biological similarity with three adjacent protected areas.

\section{METHODS}

STUDY AREA. This study was conducted from 17 March to

14 May 2011 in COMATSA (E049 $15^{\prime}$, E049 15', Figure 1). This corridor comprises one of the largest forest blocks in Madagascar;

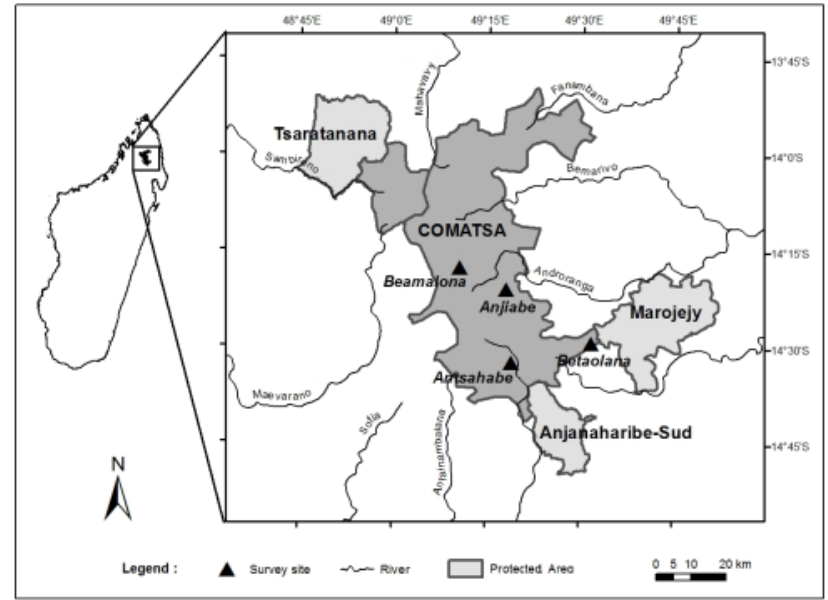

Figure 1. COMATSA area showing the location of survey sites and nearby protected areas. covering approximately 250,000 hectares and overlaps five Districts in three Regions: Andapa, Sambava, Vohémar within the SAVA Region, Ambilobe within the DIANA Region, and Bealanana within the Sofia Region. The corridor's landscape is formed by a mountain chain interspersed with a series of valleys and with elevations ranging from 75 to $2,800 \mathrm{~m}$. Three specific sites representing the southwestern flank of COMATSA were selected for surveys: Antsahabe Forest (E049 $\left.17^{\prime}, \mathrm{S} 14^{\circ} 34^{\prime}\right)$, Anjiabe Forest $\left(\mathrm{E} 049^{\circ} 18^{\prime}, \mathrm{S} 14^{\circ} 20^{\prime}\right)$ and Beamalona Forest (E049 $\left.11^{\prime}, \mathrm{S} 14^{\circ} 23^{\prime}\right)$ (Figure 1). Global list of floral species in these three sites showed that primary forest habitat is composed mainly of the following trees: Ocotea spp. (Lauraceae), Cryptocarya spp. (Lauraceae), Tina spp. (Sapindaceae), while the species indicating of disturbance such as Psiadia altissima (Asteraceae), Harungana madagascariensis (Clusiaceae), and Dionycha sp. (Melastomataceae) are the dominant trees in the secondary forest (Supplementary Material 1).

The climate in COMATSA is tropical and humid with about $2,500 \mathrm{~mm}$ annual precipitation, but can go up to $3,500-4,500 \mathrm{~mm}$. The maximum precipitation is in December whereas the minimum is in July. The rainy season runs from November to April and the dry period from May to October. The average annual temperature is approximately $20^{\circ} \mathrm{C}$, with the coldest period in July $\left(16^{\circ} \mathrm{C}\right)$ and the hottest in December $\left(24^{\circ} \mathrm{C}\right)$. Several rivers (e.g., Maevarano, Sambirano, Mahavavy, Fanambana, Bemarivo and Antainambalana) have their headwaters within COMATSA and flow down to the Indian Ocean or Mozambique Channel (Figure 1).

since 2008, one of the main activities of the WWF in northern highland of Madagascar is to include the COMATSA within SAPM sites. As such, in December 2010, the COMATSA had got its provisional protection status (Supplementary Material 2). Then, in October 2013, Forestry Department in Madagascar entrusted to WWF one-year management of this forest corridor; but this duration could, probably, be extended up to next five years until the new protected site gets its definitive protection status.

RAPID BIOLOGICAL ASSESSMENT. Rapid biological inventories of amphibians, reptiles, birds, small mammals and lemurs were carried out in the forests of Antsahabe, Anjiabe and BeamaIona by a multidisciplinary team of the Association BIODEV. In each site, surveys were conducted at 850-1,000 m, 1,000-1,600 m and above $1,600 \mathrm{~m}$ to understand the altitudinal distribution of fauna.

Several types of inventory methods were used to assess the biodiversity of COMATSA. Diurnal and nocturnal observations were conducted for all inventoried faunal groups and survey duration was six days per site. For herpetofaunal surveys, refuge examination and pitfall traps were used. Refuge examination required researchers to search under leaf litter and rocks among dead wood, leaf axils of Pandanus palms, and on tree trunks during the day and night to record species (Raxworthy 1988). At each site, over six consecutive trap days, two persons were active about three hours, respectively during the day and night. Pitfall traps consisted of buckets (15 liters in volume), with handles removed, dug into the ground and placed at $10 \mathrm{~m}$ intervals along a drift fence $100 \mathrm{~m}$ in length. The buckets were drilled with small holes in the bottom to allow water to drain (for more information on pitfall protocol, see Raxworthy 1988, Rakotomalala and Raselimanana 2003). Three trap lines by site were set in different microhabitat along the crest of a ridge and valley during six consecutive days. 
Traps were checked twice a day, at $0600 \mathrm{~h}$ and $1600 \mathrm{~h}$. No voucher specimens were taken. The encountered species were identified according to the identification keys and illustrations of Glaw and Vences (2007) and, photographs were also taken to confirm the identification of doubtful species. Photographic records were compared with specimens housed at the University of Antananarivo (Supplementary Material 3).

Forest birds were directly counted using the Mackinnon and Phillips (1993) species-list approach. Researchers walked slowly (about 1-1.5 km per hour) along pre-existing trails and recorded bird species seen or heard. Six days were spent at each site and surveys lasted about four hours in the morning and one hour and half in the afternoon, respectively from 0430-0830h and 1700-1830h when birds were most active and vocal (Scott et al. 1981).

For small mammal surveys, pitfall traps were used for terrestrial species (e.g., Soarimalala and Goodman 2003). A total of 80 Sherman live traps were also used to capture small mammals. Traps were baited with peanut butter and the distance between two consecutive traps varied according to the habitat. Traps were set on the ground, on decomposing trees, under tree roots, on tree trucks, dead leaves or litter and along river shore to maximize the chance of capture. Pitfall and Sherman traps were checked twice a day at $0600 \mathrm{~h}$ and $1600 \mathrm{~h}$.

By using pre-existing trails as transects, nocturnal and diurnal direct observation of lemurs were carried out by two experienced observers. Each transect was slowly walked, about $1 \mathrm{~km}$ per hour. Transects were walked once at night between $1900 \mathrm{~h}$ and $2230 \mathrm{~h}$ and twice during the day between $0600 \mathrm{~h}$ and 1030h, and 1500h and $1730 \mathrm{~h}$, periods covering peak lemur activity. All species-specific signs or markings were also recorded as indicators of the presence of a taxon. Sherman live traps were also used to capture small nocturnal lemurs as Microcebus and Cheirogaleus. After identification, trapped animals were released at the site of capture shortly before dusk on the same day. At each survey site, threats and pressures to the biodiversity were recorded through direct observation or by interviewing a local guide.

CONSERVATION STATUS ASSESSMENT. For each faunal group, information from the International Union for Conservation of Nature (IUCN 2014) was used to determine if recorded species were endemic to Madagascar (included regional endemicity for birds), and if they occurred in the Madagascar Protected Areas System (Figure 2), as well as to verify their conservation status. However, for the purpose of conservation prioritization, emphasis was given to those species listed in the three highest IUCN threat categories as Critically Endangered (CR), Endangered (EN), Vulnerable (VU) (Andreone et al. 2005, Rabearivony et al. 2010), although all IUCN categories were considered.

COEFFICIENT OF SIMILARITY CALCULATION. Similarity coeffi cients (S) are used to compare the degree of association in community composition between sites or samples based on presence/absence of species that areas of comparison contain (Nur et al. 1999). In this study, for conservation purposes, analysis focused only on threatened species. We compared the composition of each faunal group between pairs of sites as follows: COMATSA and Marojejy, COMATSA and Anjanaharibe-Sud, COMATSA and Tsaratanana, Marojejy and Anjanaharibe-Sud, Marojejy and Tsaratanana, and Tsaratanana and Anjanaharibe-Sud. The Jaccard coef

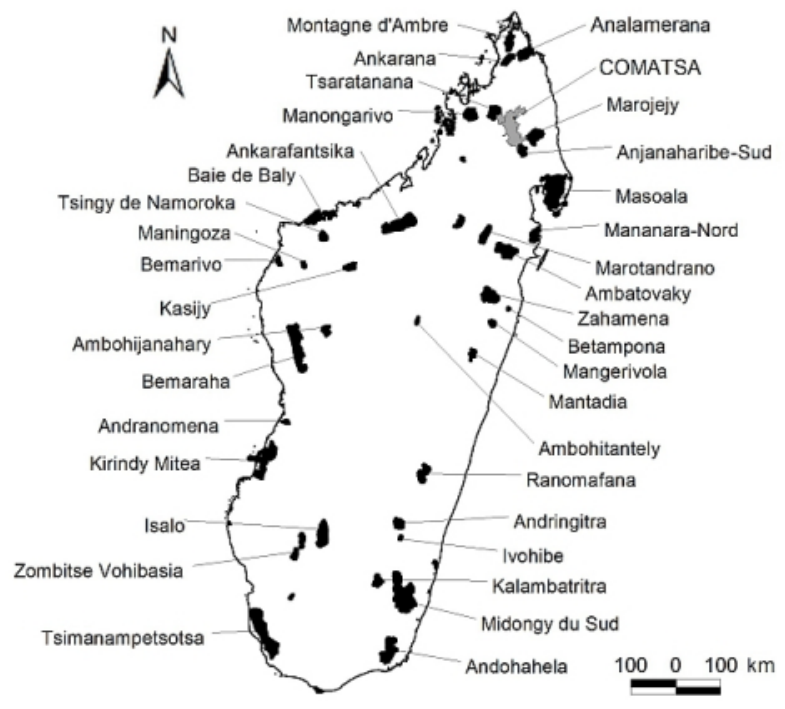

Figure 2. Localities of protected areas in Madagascar cited in the text.

ficient was used to measure similarity between finite sample sets and, according to the formula below, is defined as the size of the intersection divided by the size of the union of the sample sets (Krebs 1989).

$$
S=\frac{C}{N_{1+2}}
$$

where $\mathrm{N}_{1+2}$ is the total number of species encountered in sites 1 and 2 , and $C$ is the number of species common to both sites.

This comparison of species composition could also give insight into biogeographical trends between compared sites (Herrera-Campos et al. 2004).

\section{RESULTS}

CONSERVATION STATUS OF FAUNA IN THE COMATSA. Rapid biodiversity assessment undertaken in COMATSA and previous findings from Betaolana corridor yielded a total records of 80 species of amphibians and all are endemic (Supplementary Material 4). The COMATSA had two Endangered and 10 Vulnerable species (Table 1). Most of these threatened taxa were found at the altitude lower than 1,600 $\mathrm{m}$ and were distributed in only one to four MNP protected sites.

For reptiles, the COMATSA harbors 54 species, of which 52 are endemic, four Endangered and six Vulnerable. None of the existing Malagasy protected areas contain the Endangered chameleon Calumma vencesi and the other threatened taxa can be found in one to seven protected sites (Table 1). With the exception of the Vulnerable chameleon $C$. tsaratananense, which was found above 1,600 m, most reptile species were recorded at altitudes lower than $1,600 \mathrm{~m}$.

A total of 96 bird species were recorded in the COMATSA, of which 79 are endemic (included regionally endemic) and, according to the IUCN (2014), four are Vulnerable. The altitudinal range of these Vulnerable species varies from 450 to $1,950 \mathrm{~m}$ and each occurs within six to nine protected areas in Madagascar.

Of 28 small mammal species found in the COMATSA, only one species (Rattus rattus) is not endemic, and only one species recorded between 1,000 to 1,600 m is Vulnerable: Microgale dryas (VU). In Madagascar, this threatened mammal is recorded in only 
Table 1. Distribution of Critically Endangered (CR), Endangered (EN) and Vulnerable (VU) species recorded in COMATSA. Taxa: $a=$ Species found during this study, $b=$ Species found by other authors; Protected Areas: 1 = Ambatovaky, $3=$ Ambohitantely, $4=$ Analamazaotra, $5=$ Analamerana, $6=$ Andohahela, $7=$ Andranomena, $8=$ Andringitra, 9 = Anjanaharibe-Sud, $11=$ Ankarana, $12=$ Baie de Baly, $13=$ Bemaraha, $14=$ Bemarivo, $15=$ Betampona, $17=\mid$ vohibe, $18=$ Kalambatritra, $19=$ Kasijy, $21=$ Lokobe, 22 = Mananara-Nord, $23=$ Mangerivola, 24 = Maningoza, $25=$ Manongarivo, $26=$ Mantadia, $27=$ Marojejy, $28=$ Marotandrano, $29=$ Masoala, $30=$ Midongy du Sud 31 = Montagne d'Ambre, 32 = Ranomafana, 33 = Tsaratanana, 35 = Tsingy de Namoroka, 36 = Zahamena. For detailed list of taxa see Supplementary Material and for the location of these protected areas in Madagascar, see Figure 2.

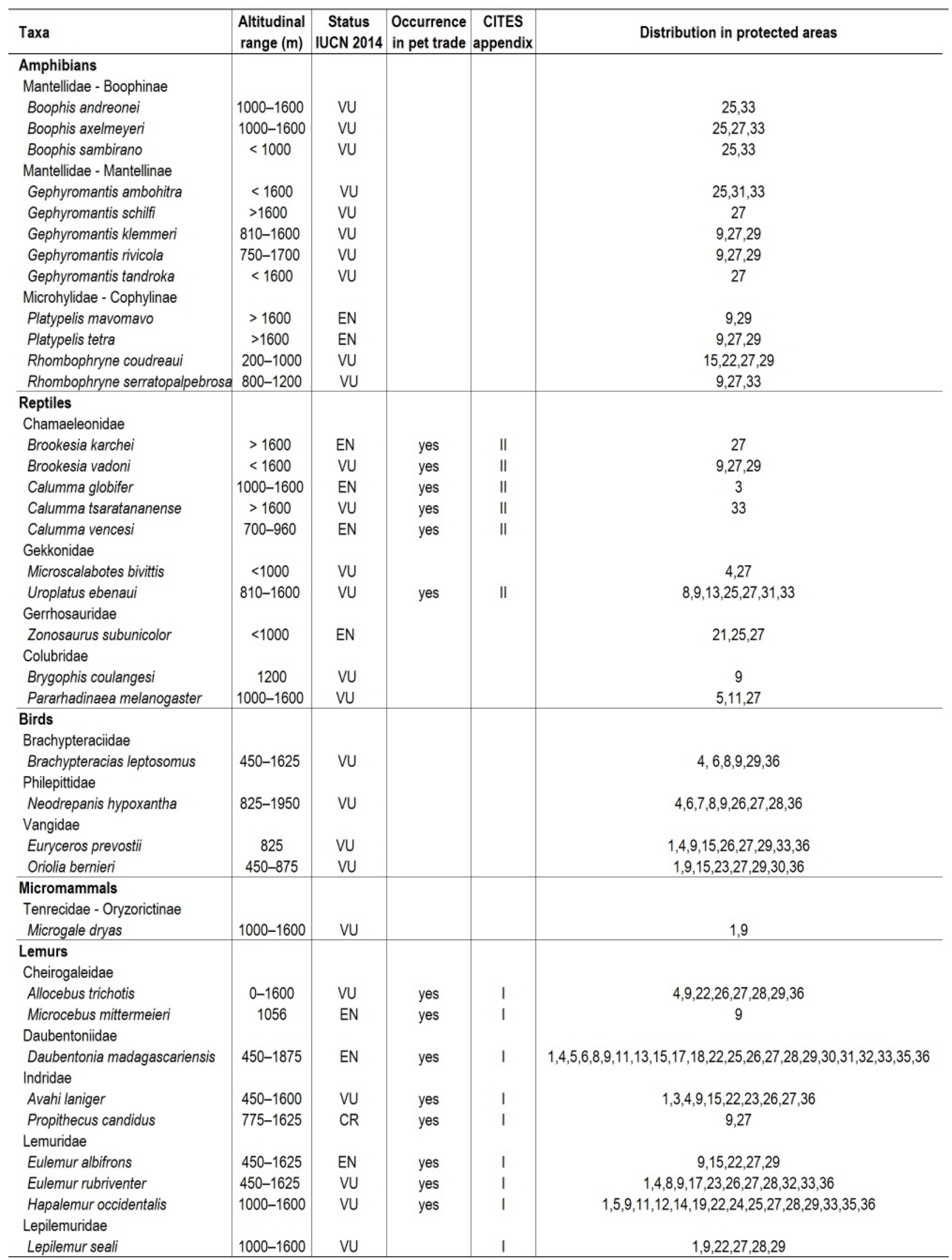


two protected sites: Ambatovaky and Anjanaharibe-Sud Specia Reserves.

All lemur taxa in Madagascar are endemic to the Island and a total of 10 species were recorded in the COMATSA. In this forest corridor, there was one Critically Endangered, three Endangered and five Vulnerable species. Of these nine threatened lemur taxa, the Critically Endangered Propithecus candidus has a very restricted distribution range within Malagasy protected areas. Despite its presence in provisionally protected Makira forest (Patel 2014), it is recorded only in two MNP sites: Marojejy National Park and Anjanaharibe-Sud Special Reserve. The endangered Daubentonia madagascariensis has the broadest distribution and has been recorded in 18 Malagasy protected areas. It has been recorded in Betaolana at $820 \mathrm{~m}$ (Goodman et al. 2003a).

VALUES OF COEFFICIENT OF SIMILARITY. The comparison of threatened herpetofauna species composition by the similarity calculation showed that COMATSA - Marojejy was the only site that had a similarity value greater than 0.50 : 0.67 and 0.60 , respectively for amphibians and reptiles (Table 2 ). This similarity was greater for birds than for herpetofauna: 0.75, 1.00 and 0.75, for COMATSA - Marojejy, COMATSA - Anjanaharibe-Sud and Marojejy - Anjanaharibe-Sud, respectively (Table 2). For small mammal communities, this similarity was not calculated as there was only one threatened species Microgale dryas (VU) recorded in the COMATSA. For the same comparison sites, COMATSA - Marojejy, COMATSA - Anjanaharibe-Sud and Marojejy - Anjanaharibe-Sud, lemurs had a greater similarity value than birds, which is, respectively, equal to $0.89,1.00$ and 0.89 (Table 2). For all faunal groups combined, COMATSA - Tsaratanana, Marojejy - Tsaratanana and Anjanaharibe-Sud - Tsaratanana had consistent similarity values less than 0.50. Tsaratanana may have less biogeographical affinity to the southern sites like COMATSA, Marojejy and Anjanaharibe-

Table 2. Coefficient of similarity for amphibians, reptiles, birds and lemurs. $(\mathrm{N} 1+2=$ Total number of species encountered in sites 1 and 2, C = Number of species common to both sites, $\mathrm{S}=$ Similarity index).

\begin{tabular}{|c|c|c|c|c|c|c|}
\hline & 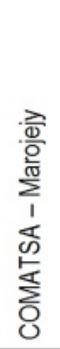 & 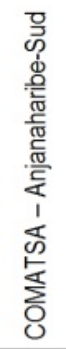 & 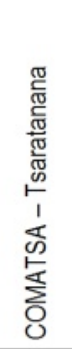 & 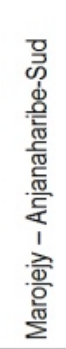 & 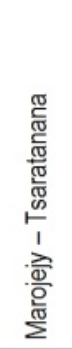 & 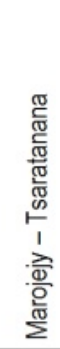 \\
\hline \multicolumn{7}{|c|}{ Amphibians } \\
\hline$N_{1+2}$ & 12 & 12 & 12 & 9 & 11 & 9 \\
\hline$C$ & 8 & 5 & 5 & 4 & 2 & 1 \\
\hline$S$ & 0.67 & 0.42 & 0.42 & 0.44 & 0.18 & 0.11 \\
\hline \multicolumn{7}{|c|}{ Reptiles } \\
\hline$N_{1+2}$ & 10 & 10 & 10 & 7 & 7 & 4 \\
\hline$C$ & 6 & 3 & 2 & 2 & 1 & 1 \\
\hline$S$ & 0.60 & 0.30 & 0.20 & 0.29 & 0.14 & 0.25 \\
\hline \multicolumn{7}{|l|}{ Birds } \\
\hline$N_{1+2}$ & 4 & 4 & 4 & 4 & 3 & 4 \\
\hline C & 3 & 4 & 1 & 3 & 1 & 1 \\
\hline$S$ & 0.75 & 1.00 & 0.25 & 0.75 & 0.33 & 0.25 \\
\hline \multicolumn{7}{|c|}{ Lemurs } \\
\hline$N_{1+2}$ & 9 & 9 & 9 & 9 & 8 & 9 \\
\hline C & 8 & 9 & 3 & 8 & 3 & 3 \\
\hline$S$ & 0.89 & 1.00 & 0.33 & 0.89 & 0.38 & 0.33 \\
\hline
\end{tabular}

Sud. Therefore, biogeographical affinity was greater for the herpetofauna species in COMATSA - Marojejy than in others sites whilst, for birds and lemurs, this affinity was much greater in COMATSA - Marojejy, COMATSA - Anjanaharibe-Sud and Marojejy - Anjanaharibe-Sud.

\section{DISCUSSION}

COMATSA AS HOME TO ENDEMIC AND THREATENED TAXA.

The diversity and high endemism of different faunal groups in northeastern Madagascar have been highlighted by numerous authors (Glaw and Vences 2003, Goodman et al. 2003b, Hawkins and Goodman 2003, Raxworthy 2003). The limited geographical range, combined with continuing decline in the extent and quality of habitat are the main pressures for most of threatened species encountered in this study (IUCN 2014). Given the alarming degradation caused by unsustainable exploitation of rosewood in nearby protected areas of COMATSA such as Marojejy and Masoala, and illegal mining in Anjanaharibe-Sud (Innes 2010, Randriamalala and Liu 2010, Patel and Welch 2013), the establishment of the COMATSA protected corridor would create an additional refuge for these threatened species as it is comparatively safer from these pressures. Selective examples can be taken to illustrate the significant contribution of COMATSA to ensuring the survival of many endemic and threatened taxa. The endangered amphibian Platypelis tetra is a Pandanus-dwelling species (Lehtinen 2002, Andreone et al. 2003), and is threatened by the collection of these plants for making the roofs of huts (IUCN 2014). It is known from Anjanaharibe-Sud, Masoala and Marojejy at 600-1,250 m (ibid), and its occurrence above $1,600 \mathrm{~m}$ in the COMATSA extended its known range to the higher elevation. This higher altitudinal range may provide further protection to this species, especially, when taking into account the recent disturbance in the lowland forests of Masoala and Marojejy during the last political crisis (2009-2013) in Madagascar (Innes 2010, Randriamalala and Liu 2010). There is no formally protected site inhabited by the endangered chameleon Calumma vencesi and it is found only in Betaolana Forest corridor with a range of $590 \mathrm{~km} 2$ and between 700 to $960 \mathrm{~m}$ (Andreone et al. 2001, IUCN 2014). Known as disturbance sensitive chameleon (Andreone et al. 2001), its presence in Betaolana could justify the inclusion of COMATSA in the expanded Madagascar Protected Areas System.

Regarding threatened bird species, the Vulnerable Brachypteracias leptosomus was found within six Malagasy protected areas (Analamazaotra, Andohahela, Andringitra, Anjanaharibe-Sud, Masoala and Zahamena), and its declining trend is likely to become rapid over the next ten years (IUCN 2014). For conservation goals, IUCN (2014) recommended the size of the area of suitable habitat for this secretive bird and, according to the present results; COMATSA would be one of the best sites for its protection. As far as small mammals are concerned, the Vulnerable Microgale dryas is known only from Ambatovaky and Anjanaharibe-Sud, at the altitude between 500-940 m with an extent of occurrence of less than $20,000 \mathrm{~km}^{2}$ (ibid). Its presence in provisionally protected COMATSA extends its northern range and reinforces its protection.

Concerning lemur species, the Critically Endangered Propithecus candidus is one the world's 25 most endangered primates and is found, apart from Makira provisional protected area, only in two MNP sites, from 700-1,875 m at Anjanaharibe-Sud and Marojejy (IUCN 2014, Patel 2014). Less than 2,000 individuals of this species remain in the wild, and none ever survived in captivity 
(Patel 2014). All lemur species in Anjanaharibe-Sud and Marojejy are currently considered by the IUCN as threatened, except for the greater dwarf lemur Cheirogaleus major, due to a variety of new and ongoing threats during the last five years (2009-2013) (Patel and Welch 2013). Therefore, the occurrence of Propithecus candidus at the COMATSA, in Antsahabe and Anjiabe sites, would strengthen its protection against such unfavorable circumstances.

In this provisionally protected site, human disturbances to the forest ecosystem and indeed, to the biodiversity, are more severe in its northeastern part (around Bemarivo and Fanambana rivers), although it is still relatively less populated than other parts of corridor (Garreau and Manantsara 2003). This northeastern zone is visited and controlled only by the local forestry representative almost every decade as it is a landlocked area with extremely difficult access (J. Rabearivony pers. obs.). During this study, most threats to biodiversity observed in the COMATSA have previously been reported by Garreau and Manatsara (2003) and Razafy and Andriamarosolo (2010). This includes (i) deforestation due to hill rice cultivation, (ii) habitat degradation caused by the extraction of a variety of products such as wood for construction, and bark of the plant Evodia sp. (Rutaceae) for fermenting sugar cane to produce a local spirit known as betsabetsa, (iii) lemurhunting and (iv) artisanal mining. Despite these pressures, the major parts of forest in the corridor keep their primary habitat feature (ibid). Currently, many projects are run by the WWF in the COMATSA to strengthen its protection (ibid). As one significant milestone, the process of definitive protection of 250,000 hectares of forest is now undergone. The delimitation of this provisionally protected forest, entailing some 80,700 hectares of surface area, is surrounded by 33 local associations to ensure the wise use of their forests via management transfer of natural resources program known as GELOSE (Gestion Locale Sécurisée). The number of associations is still increasing and reached up to 41 in 2014. The remaining surface of 169,300 hectares of this provisionally protected corridor constitutes the forest core area where found most species of conservation target for the definitive protected site. In peripheral zones of COMATSA, a total of 120 hectares of bare areas around Doany, Ambodipaiso, Mangindrano, Anesika and Analalatsaka villages were reforested, mainly by Eucalyptus tree (Myrtaceae), allowing local populations to reduce their dependence on forest wood for energy and construction. The success rate of this reforestation is estimated at $80 \%$. To reconnect the different forest fragments in the COMATSA, about 300 hectares of land between forest blocks was passively restored, allowing natural colonization by shrubs and trees and other secondary succession species.

COMATSA AS A GENETIC BRIDGE. Habitat corridors have been shown to be valuable for the conservation of various groups of wildlife and in various situations, although individual species may vary in their use of corridors (MacDonald 2003). For herpetofauna species in the COMATSA, the values of similarity between COMATSA - Marojejy of 0.67 and 0.60 , respectively for amphibians and reptiles, suggested the role played by this corridor in maintaining herpetofaunal diversity between both sites. Large habitat corridors like COMATSA represent a key element for herpetofaunal conservation, maintaining genetic connectivity between fragments and, therefore, reducing the risk of inbreeding depression (Dixo and Metzger 2009, Dixo et al. 2009). This is especially true for the amphibians and reptiles that have very limited dispersal capacity (ibid), and which are extremely sensitive to habitat and microhabitat modifications (Gibbons et al. 2000). As the present results cover only the southern part of COMATSA and the northern and northeastern areas have never been surveyed, this sampling bias may explain the values of similarity less than 0.50 between COMATSA - Tsaratanana for all faunal groups. For all site combinations with Tsaratanana (COMATSA - Tsaratanana, Marojejy - Tsaratanana and Anjanaharibe-Sud - Tsaratanana), a long term monitoring program covering different parts of these forests (Marojejy, COMATSA, Anjanaharibe-Sud and Tsaratanana) should be established to get more representative results and to understand this relatively low value of similarity $(S<0.50)$. This program should take into consideration all factors (biotic and abiotic) that may influence herpetofaunal distributions such as habitat variability, altitudinal gradient, geographical or physical barriers and season. The most updated taxonomy should be used for this, as species misidentification may have significant effects on similarity value.

Many avian studies have shown that landscape corridors play an important role in maintaining biodiversity and ecological processes (Dunning Jr. et al. 1995, sieving et al. 2000), improving population persistence (Lens et al. 2002), and overcoming the genetic and demographic problems of small and isolated populations (Fahrig and Merriam 1994). Knowing that the effectiveness of corridor's functions depends on the size and disturbance gradient of forest fragments (MacDonald 2003, Pardini et al. 2005), large forested habitat like COMATSA could ensure the genetic exchange of fauna among its surrounding forests (Marojejy, AnjanaharibeSud and Tsaratanana), especially for those species of high dispersal capacity as birds (Bélisle and Desrochers 2002). This may explain the high geographical affinity of birds among these forests with respective similarity value of 0.75 for COMATSA - Marojejy, 1.00 for COMATSA - Anjanaharibe-Sud and 0.75 for Marojejy - Anjanaharibe-Sud.

Lemur species are the most studied faunal group among Malagasy vertebrates (e.g., Tattersall 1982, 2013, Mittermeier et al. 2008). They have been researched in almost all protected areas in Madagascar (e.g., Patel and Welch 2013), and this research is now extending to some unprotected forests (Lehman et al. 2006, Axel and Maurer 2011). As COMATSA is separated from its neighboring forests only by seasonal roads or footpaths, lemurs can disperse within forest blocks easily by leaping and/or running on tree branches. Lehman et al. (2006) reported the ability of some lemur species (e.g., Propithecus sp.) to traverse the open areas between forest fragments. Therefore, our sampling bias combined with the high mobility of lemurs may explain the high similarity value between COMATSA - Marojejy, COMATSA - Anjanaharibe-Sud and Marojejy-Anjanaharibe-Sud. It is also noteworthy that the high diversity of lemurs in the COMATSA may contribute to the maintenance of ecological process within its natural forest through the frugivory and seed dispersal capacity by these primates (Dew and Wright 1998, Lahann 2007, Razafindratsima et al. 2014).

\section{CONCLUSION}

The provisionally protected forest corridor between Marojejy, Anjanaharibe-Sud and Tsaratanana protected areas (COMATSA) contains several endemic and threatened taxa of amphibians, reptiles, birds, small mammals and lemurs. The reptiles and amphibians in the COMATSA showed high similarity with Marojejy. This similarity was more significant between COMATSA - Marojejy, CO- 
MATSA - Anjanaharibe-Sud and Marojejy-Anjanaharibe-Sud for bird and lemur species. The high similarity between COMATSA and its nearby reserves corroborate the landscape vision initiated by WWF for considering the COMATSA and several northern protected areas as one important conservation unit. This study confirmed the effectiveness of large forest corridor in maintaining species diversity and, therefore, supports the inclusion of COMATSA to the new protected area system in Madagascar as SAPM. Worldwide, as habitat fragmentation is a major biodiversity issue, connectivity between COMATSA and its three adjacent protected areas (Marojejy, Anjanaharibe-Sud and Tsaratanana) should be maintained permanently to ensure the genetic exchange between these different forest blocks. This will be chivied only by collaboration between and involvement of all concerned stakeholders, including 41 local associations surrounding the COMATSA.

\section{ACKNOWLEDGEMENTS}

Biodiversity inventory in the COMATSA was financially supported by the Air France and GoodPlanet via the World Wildlife Fund Madagascar and West Indian Ocean (WWF MWIOPO), 'Programme Holistique de Conservation des Forêts à Madagascar (PHCF)'. We are especially grateful to Nanie Ratsifandrihamanana, the Country Director of WWF MWIOPO for allowing us to publish this work and Gérard Rambeloarisoa, the Conservation Director of WWF MWIOPO for supporting the PHCF's activities. Voahirana Randriambola, the coordinator of Footprint program WWF MWIOPO, has provided support and guidance for many years in running PHCF. Research permit for this study was issued by the 'Ministère de I'Environnement, de l'Ecologie, de la Mer et des Forêts', Antananarivo. Fieldwork was completed by the biologists from BIODEV Association and logistically facilitated by the team from PHCF Andapa/Bealanana: Fidimanana, Falizara, Léandre Razafilahy, Christophe Ramanantsoa, Jean Nöel, Odon Andrianarivelo, Zafinandriana Velonjara and Marie Heleine. For this study, administrative facility was kindly ensured by Tahiana Razafiarijaona and Erica Antilahy. Marius Rakotondratsima prepared Figures 1 and 2 and Russell Thorstrom made helpful comments in earlier version of the manuscript. Local and regional Forestry Service personnel, respectively from Bealanana and Antsohihy, as well as local communities around the three specific sites (Beamalona, Anjiabe and Antsahabe forests) were also acknowledged for their invaluable support, time and expertise.

\section{REFERENCES}

Andreone, F., Mattioli, F., Jesu, R. and Randrianirina, J. E. 2001. Two new chameleons of the genus Calumma from north-east Madagascar, with observations of hemipenial morphology in the Calumma furcifer group (Reptilia, Squamata, Chameleonidae). Herpetological Journal 11: 53-68.

Andreone, F., Fenolio, D. B. and Walvoord, M. E. 2003. Two unknown arboreal frogs (genus Platypelis) described from the rainforests northern Madagascar (Microhylidae: Cophylinae). Current Herpetology 22, 2: 91-100. (doi:10.5358/hsj.22.91)

Andreone, F., Cadle, J. E., Cox, N., Glaw, F., Nussbaum, R. A., et al. 2005. Species review of amphibian extinction risks in Madagascar: Conclusion from global amphibian assessment. Conservation Biology 19, 6: 1790-1802. (doi:10.1111/j.1523-1739.2005.00249.x)

Axel, A. C. and Maurer, B. A. 2011. Lemurs in a complex landscape: mapping species density in subtropical dry forests of southwestern Madagascar using data at multiple levels. American Journal of Primatology 73, 1: 38-52. (doi:10.1002/ajp.20872)
Bélisle, M. and Desrochers, A. 2002. Gap-crossing decisions by forest birds: an empirical basis for parameterizing spatially-explicit, individual-based models. Landscape Ecology 17, 3: 219-231. (doi:10.1023/A:1020260326889)

Boyd, C., Brooks, T. M., Butchart, S. H. M., Edgar, G. J., da Fonseca, G. A. B., et al. 2008. Spatial scale and the conservation of the threatened species. Conservation Letters 1, 1: 37-43. (doi:10.1111/j.1755-263X.2008.00002.x)

Dew, J. L. and Wright, P. 1998. Frugivory and seed dispersal by four species of primates in Madagascar's eastern rainforest. Biotropica 30, 3: 425-437. (doi:10.1111/j.1744-7429.1998.tb00076.x)

Dixo, M. and Metzger, J. P. 2009. Are corridors, fragment size and forest structure important for the conservation of leaf-litter lizards in a fragmented landscape? Oryx 43, 3: 435-442. (doi:10.1017/S0030605309431508)

Dixo, M., Metzger, J. P., Morgante, J. S. and Zamudio, K. R. 2009. Habitat fragmentation reduces genetic diversity and connectivity among toad populations in the Brazilian Atlantic coastal forest. Biological Conservation 142, 8: 1560-1569. (doi:10.1016/j.biocon.2008.11.016)

Dunning Jr., J. B., Borgella Jr., R., Clements, K and Meffe, G. K. 1995. Patch isolation, corridor effects, and colonization by a resident sparrow in a managed pine woodland. Conservation Biology 9, 3: 542-550. (doi:10.1046/j.15231739.1995.09030542.x)

Durkin, L., Steer, M. D. and Bell, E. M. S. 2011. Herpetological surveys of forest fragments between Montagne d'Ambre National Park and Ankarana Special Reserve, northern Madagascar. Herpetological Conservation and Biology 6, 1: $114-126$.

Fahrig, L. and Merriam, G. 1994. Conservation of fragmented populations. Conservation Biology 8, 1: 50-59. (doi:10.1046/j.1523-1739.1994.08010050.x)

Ganzhorn, J. U., Lowry II, P. P., Schatz, G. E. and Sommer, S. 2001. The biodiversity of Madagascar: one of the world's hottest hotspots on its way out. Oryx 35, 4: 1-3. (doi:10.1046/j.1365-3008.2001.00201.x)

Garreau, J.-M. and Manantsara, A. 2003. The protected-area complex of the Parc National de Marojejy and the Réserve Spéciale d'Anjanaharibe-Sud. In: The Natural History of Madagascar. S. M Goodman and J. P. Benstead (eds.), pp 1451-1458. The University of Chicago Press, Chicago.

Gibbons, J. W., Scott, D. E., Ryan, T. J., Buhlmann, K. A., Tuberville, T. D., et al. 2000. The global decline of reptiles, déjà vu amphibians. Bioscience 50,8 : 653-666. (doi:10.1641/0006-3568(2000)050[0653:TGDORD]2.0.C0;2)

Glaw, F and Vences, M. 2003. Introduction to amphibians. In: The Natural History of Madagascar. S. M Goodman and J. P. Benstead (eds.), pp 883-898. The University of Chicago Press, Chicago.

Glaw, F. and Vences, M 2007. A Fieldguide to the Amphibians and Reptiles of Madagascar. Third edition. Cologne, Vences and Glaw Verlag, Köln, Germany.

Goodman, S. M., Raherilalao, M. J., Rakotomalala, D. Raselimanana, A., Schütz, H. \& Soarimalala, V. 2003a. Les lémuriens. In: Nouveaux Résultats d'inventaires Biologiques faisant Référence à l'Altitude dans la Région des Massifs Montagneux de Marojejy et d'Anjanaharibe-Sud. S. M. Goodman \& L. Wilmé (eds.), pp 279-286. Recherche pour le Développement, Séries Sciences Biologiques 19.

Goodman, S. M., Ganzhorn, J. U. and Rakotondravony, D. 2003b. Introduction to the mammals. In: The Natural History of Madagascar. S. M Goodman and J. P. Benstead (eds.), pp. 1159-1186. The University of Chicago Press, Chicago.

Hawkins, A. F. A. and Goodman, S. M. 2003. Introduction to the birds. In: The Natural History of Madagascar. S. M Goodman and J. P. Benstead (eds.), pp 1019-1044. The University of Chicago Press, Chicago.

Herrera-Campos, M. de L. Á., Lücking, R., Pérez, R.-E., Campos, Á., Colín, P. M. and Peña, A. B. 2004. The foliicolous lichen flora of Mexico: Biogeographical affinities, altitudinal preference, and an updated checklist of 293 species. The lichenologist 36, 5: 309-327. (doi:10.1017/S0024282904014483)

Innes, J. L. 2010. Madagascar rosewood, illegal logging and the tropical timber trade. Madagascar Conservation \& Development 5, 1: 6-10. (doi:10.4314/mcd.v5i1.57335)

IUCN 2014. The IUCN Red list of Threatened Species <http://www.iucnredlist.org> downloaded on 12 September 2014.

Krebs, C. 1989. Ecological Methodology. Harper and Row, New York. 
Lahann, P. 2007. Feeding ecology and seed dispersal of sympatric cheirogaleid lemurs (Microcebus murinus, Cheirogaleus medius, Cheirogaleus major) in the littoral rainforest of south-east Madagascar. Journal of Zoology, London 271, 1: 88-98. (doi:10.1111/j.1469-7998.2006.00222.x)

Lehman, S. M., Ratsimbazafy, J. Rajaoson, A. and Day, S. 2006. Ecological correlates to lemur community structure in southeast Madagascar. International Journal of Primatology 27, 4: 1023-1040. (doi:10.1007/s10764-006-9058-8)

Lehtinen, R. M. 2002. The use of screw pines (Pandanus spp.) by amphibians and reptiles in Madagascar. Herpetological Bulletin 82: 20-25.

Lens, L., Van Dongen, S., Norris, K., Githiru, M. and Matthysen, E. 2002. Avian persistence in fragmented rainforest. Science 298: 1236-1238. (doi:10.1126/science.1075664)

MacDonald, M. A. 2003. The role of corridor in biodiversity conservation in production forest landscapes: a literature review. Tasforests 14: 41-52.

MacKinnon, J. and Phillips, K. 1993. A Field Guide to the Birds of Borneo, Sumatra, Java and Bali. Oxford University Press, Oxford.

Mittermeier, R. A, Hawkins, F., Rajaobelina, S. and Langrand, O. 2005. Wilderness conservation in a biodiversity hotspot. International Journal of Wilderness 11: 42-46.

Mittermeier, R. A., Ganzhorn, J. U., Konstant, W. R., Glander, K., Tattersall, I. et al. 2008. Lemur diversity in Madagascar. International Journal of Primatology 29, 6: 1607-1656. (doi:10.1007/s10764-008-9317-y)

Myers, N., Mittermeier, R. A., Mittermeier, C. G., da Fonseca, G. A. B. and Kent, J. 2000. Biodiversity hotspots for conservation priorities. Nature 403: 853-858. (doi:10.1038/35002501)

Nagendra, H. 2008. Do parks work? Impact of protected areas on land cover clearing. Ambio 37, 5: 330-337. (doi:10.1579/06-R-184.1)

Nur, N., Jones, S. L. and Geupel, G. R. 1999. A Statistical Guide to Data Analysis of Avian Monitoring Programs. U.S. Department of the Interior, Fish and Wildlife Service, BTP-R6001-1999, Washington. Available at <http://ow.ly/QHMJ8>

Pardini, R., Marques de Souza, S., Braga-Neto, R. and Metzger, J. P. 2005. The role of forest structure, fragment size and corridors in maintaining small mammal abundance and diversity in an Atlantic forest landscape. Biological Conservation 124, 2: 253-266. (doi:10.1016/j.biocon.2005.01.033)

Patel, E. R. 2014. Silky sifaka, Propithecus candidus Grandidier 1871. In: Primates in Peril: The World's 25 Most Endangered Primates 2012-2014. C. Schwitzer et al. (eds.), pp 38-43. IUCN/SSC Primate Specialist Group (PSG), International Primatological Society and Conservation International, Arlington, USA.

Patel, E. R. and Welch, C. 2013. Marojejy National Park and Anjanaribe Sud Special Reserve. In: Lemurs of Madagascar: A Strategy for their Conservation 2013-2016. C. Schwitzer, R. A. et al. (eds.), pp 54-55. IUCN/SSC Primate Special Group, Conservation International, Bristol Conservation and Science Foundation.

Rabearivony, J., Thorstrom, R., Rene de Roland, L.-A., Rakotondratsima, M., Andriamalala, T. R. A. et al. 2010. Protected area surface extension in Madagascar: Do endemism and threatened species remain useful criteria for site selection? Madagascar Conservation \& Development 5, 1: 35-47. (doi:10.4314/mcd.v5i1.57338)

Raherilalao, M. J. \& Goodman, S. M. 2003. Diversité de la faune avienne des massifs d'Anjanaharibe-Sud, du Marojejy et de la forêt de Betaolana, et importance du couloir forestier dans la conservation des oiseaux forestiers. In: Nouveaux résultats d'inventaires biologiques faisant référence à l'altitude dans la région des massifs montagneux de Marojejy et d'Anjanaharibe-Sud. S. M. Goodman \& L. Wilmé (eds.), pp 203-230. Recherche pour le développement, Séries Sciences Biologiques 19.

Rakotomalala, D. \& Raselimanana, A. P. 2003. Les amphibiens et les reptiles des massifs de Marojejy, d'Anjanaharibe-Sud et du couloir forestier de Betaolana. In: Nouveaux résultats d'inventaires biologiques faisant référence à l'altitude dans la région des massifs montagneux de Marojejy et d'Anjanaharibe-Sud. S. M. Goodman \& L. Wilmé (eds.), pp 147-202. Recherche pour le développement, Séries Sciences Biologiques 19.

Randriamalala, H. and Liu, Z. 2010. Rosewood of Madagascar: between democracy and conservation. Madagascar Conservation \& Development 5, 1: 11-22. (doi:10.4314/mcd.v5i1.57336)

Raxworthy, C. J. 1988. Reptiles, rainforest and conservation in Madagascar. Biolo gical Conservation 43, 3: 181-211. (doi:10.1016/0006-3207(88)90113-9)
Raxworthy, C. J. 2003. Introduction to the reptiles. In: The Natural History of Madagascar. S. M Goodman and J. P. Benstead (eds.), pp 934-949. The University of Chicago Press, Chicago.

Razafindratsima, O. H., Jones T. A. and Dunham A. E. 2014. Patterns of movement and seed dispersal by three lemur species. American Journal of Primatology 76, 1: 84-96. (doi:10.1002/ajp.22199)

Razafy, F. L. \& Andriamarosolo, I. 2010. Conservation des lémuriens via la conservation de leurs habitats et le développement communautaire dans les corridors de Betaolana et Tsaratanana-Betaolana, région SAVA. Lemur News 15: $55-60$.

Scott, J. M., Ramsey, F. L. and Kepler, C. B. 1981. Distance estimating as a variable in estimating bird numbers. In: Estimating Numbers of Terrestrial Bird. C. J. Ralph and J. M. Scott (eds.), pp 334-340. USGS Publications Warehouse.

Sieving, K. E., Willson, M. F. and de Santo, T. L. 2000. Defining corridor functions for endemic birds in fragmented south-temperate rainforest. Conservation Biology 14, 4: 1120-1132. (doi:10.1046/j.1523-1739.2000.98417.x)

Soarimalala, V. \& Goodman, S. M. 2003. Diversité biologique des micromammifères non volants (Lipotyphla et Rodontia) dans le complexe Marojejy - Anjanaharibe-Sud. In: Nouveaux Résultats d'Inventaires Biologiques faisant Référence à l'Altitude dans la Région des Massifs Montagneux de Marojejy et d'Anjanaharibe-Sud. S. M. Goodman \& L. Wilmé (eds.), pp 231-278. Recherche pour le développement, Séries Sciences Biologiques 19.

Tattersall, I. 1982. The Primates of Madagascar. New York, Colombia University Press.

Tattersall, I. 2013. Understanding species-level primate diversity in Madagascar. Madagascar Conservation \& Development 8, 1: 7-12. (doi:10.4314/mcd.v8i1.2)

\section{SUPPLEMENTARY MATERIAL. AVAILABLE ONLINE ONLY.}

S1. WWF 2011. Inventaire Biologique du Grand Couloir Forestier reliant le Parc National d'Anjanaharibe-Sud et la Réserve Naturelle Intégrale de Tsaratanana.

S2. WWF/Foundation GoodPlanet/AirFrance 2013. Programme Holistique de Conservation des Forêts à Madagascar : Quatre années de mise en œuvre, Décembre 2008 à Octobre 2012.

S3. Photographic records of herpetofauna from COMATSA.

S4. List of species recorded in COMATSA, distribution, endemism and IUCN Status. 